\title{
The IS-LM Model and the Liquidity Trap Concept: From Hicks to Krugman
}

"So the General Theory of Employment is the Economics of Depression" (Hicks, 1937, p. 155).

"Depression economics is back" (Krugman, [1999] 2000, p. 156).

\section{Introduction}

One of the main features of John Hicks's 1937 "Mr. Keynes and the Classics" is his identification of the assumption that there is a floor to the rate of interest on the left part of the LM curve as the central difference between J. M. Keynes's 1936 General Theory and "classical" economics, a judgment that he repeated on other occasions ([1939] 1946, 1950, 1957). The notion of a "liquidity trap" (a phrase coined by Dennis Robertson 1936, 1940, albeit in a different context) was conspicuous in macroeconomic textbooks of the 1950s and 1960s (see, e.g., Hansen, 1953; Ackley, 1961; Bailey, 1962), but it gradually receded into the background until it came to the fore again in the recent literature triggered by the Japanese depression and the experience of low inflation and low nominal interest rates in the United States and Europe in the late 1990s (see, e.g, McKinnon and Ohno, 1997, ch. 5; Fuhrer and Madigan, 1997; Krugman, 1998, [1999] 2000; Svensson, 2001; Woodford, 2002; special issues of the Journal of Money Credit and Banking, November 2000, and of the Journal of the Japanese and International Economics, December 2000; Benhabib et al, 2002). The revival of interest in the notion of a liquidity trap as a constraint on the effectiveness of monetary policy is also visible in connection with references by modern textbooks to the Japanese depression (see, e.g., Gordon, 2000; Froyen, 2002; Colander and Gamber, 2002; Gärtner, 2003; Mankiw, 2003; Krugman and Obstfeld, 2003).

Whereas the liquidity trap literature traditionally associated with Keynes (1936) and Hicks (1937) concerned the existence of a positive floor to the interest rate, the recent approach investigates the possibility of a zero lower bound on interest rates. This is in part explained by the shift from Keynes's model - where the long-term interest rate is the relevant opportunity cost in money demand, and expectations about the future values of that long rate are assumed to be regressive or inelastic - to the formulation of money demand in terms of the short-term nominal interest rate, which affects the long rate through the expectations theory of the term structure of interest rates.

The purpose of the present paper is to discuss how the development of the liquidity trap concept is associated with the interpretation of the IS-LM model in general and the LM curve in particular, with emphasis on the original formulation by Hicks and the new interpretation put forward by Paul Krugman and others. The next section argues that the 1937 article should be seen against the background of Hicks' Value and Capital. Section 2 also shows how Hicks's notion of an interest rate floor grew out of his theory of the termstructure advanced in the 1939 book and mentioned in the 1937 article. Hicks's emphasis on the liquidity trap as the dividing line between Keynes and the "classics" is discussed in section 3. The development of the IS-LM model and the liquidity trap concept by Lange (1938), Modigliani (1944) and Hansen $(1949,1953)$ is the topic of section 4. The modern approach to the liquidity trap is discussed in sections 5 and 6 . It is shown that the recent literature shares with Hicks ([1939] 1946) the view that under liquidity trap conditions the central bank looses its ability to control the price level. Section 6 brings expectations into the picture. 


\section{Hicks on the rate of interest minimum}

The importance of Value and Capital for an understanding of the framework of the 1937 ISLM article was pointed out by Hicks himself. Hicks (1979, p. 990) explained how his diagrammatic representation of equilibrium in three markets (goods, money and bonds) on a two-dimmensional diagram was based on his work on three-way exchange, eventually published as chapter 5 of his 1939 book. In correspondence with Warren Young (1987, p. 98), Hicks recalled that "during those years (34-38 inclusive) my thought was mainly directed to the writing of Value and Capital (to be published in early '39); anything else was a side-line. Not even an independent side-line". This section discusses how the 1939 book influenced Hicks's 1937 article in two ways: the general relation between price expectations and stability, and the determination of interest rates.

In part III of Value and Capital Hicks introduced the method of "temporary equilibrium" in order to discuss economic dynamics. Equilibrium is defined over a period of time (the "Hicksian week") when supply and demand in the various markets are adjusted to price expectations held at the start of the period ("Monday"). It was in that context that Hicks introduced the notion of elasticity of price expectations to study the effect of actual prices on price-expectations. Hicks ([1939] 1946, p. 205) defined the elasticity of a "person's expectations of the price of commodity $\mathrm{X}$ as the ratio of the proportional rise in expected future prices of $X$ to the proportional rise in its current price". If price expectations are completely inelastic (zero elasticity), individuals interpret price changes as temporary. If the elasticity of expectations is unity, price changes are expected to be permanent. As long as elasticities of expectations are zero, any change in current prices will bring about large substitution effects over time in markets for inputs and outputs, which will stabilize the economic system. But, if changes in current prices are expected to be permanent there will be no opportunities left for substitution over time. As pointed out by Hicks (p. 251), the case of unity elasticities of expectations was at the time implicitly taken for granted by most economists, without realizing its implications for stability analysis. ${ }^{1}$ If elasticities of expectation are unity, the expected future price level changes together with current prices, which precludes stabilization through a reduction in the expected real rate of interest and leads to cumulative falling prices.

Technically, then, the case where elasticities of expectations are equal to unity marks the dividing line between stability and instability ... The proposition which we have thus established is perhaps the most important proposition in economic dynamics (Hicks [1939] 1946, p. 255).

We have assumed so far a given (nominal) rate of interest, but changes in current prices (expected to remain at the new higher or lower level) will affect the demand for money and therefore, for a given money supply, will bring about changes in the interest rate required to equilibrate the market for money. An increase of the interest rate is effective to check a rise in prices, but in the case of falling prices the interest rate mechanism may be unable to stabilize the economy.

If the rate of interest was reasonably high to begin with, it seems possible that this reaction may take place without difficulty. But if the rate of interest is very low to begin with, it may be impossible for it to fall further - since... securities are inferior substitutes for money, and can never command a higher price than money. In this case, the system does not merely suffer from imperfect stability; it is absolutely unstable. (Hicks [1939] 1946, p. 259).

The notion that the central bank cannot avoid a process of falling prices once the interest rate hits its minimum level is an important feature of the depression, according to Hicks. It is 
based on his hypothesis - advanced in chapter XIII of Value and Capital - that the short-term rate of interest is determined by transaction costs, that is, by the lack of general acceptability or imperfect "moneyness" of very short bills (p. 166). Long rates are then determined by expectations about the future course of the short rate according to the theory of the term structure introduced in chapter XI of that book. Hicks's theory of interest was developed as a reaction against Keynes's (1936, ch. 13) view that the current rate of interest is determined by risk and uncertainty about its future value. In a famous passage, Hicks (p. 164) pointed out that "to say that the rate of interest on perfectly safe securities is determined by nothing else but uncertainty of future interest rates seems to leave interest hanging by its own bootstraps; one feels an obstinate conviction that there must be more in it than that." Hicks's solution is that while the current long rate depends on the expected short rates, the current short rate is not dependent on expectations, but on the current supply and (transactions) demand for money. Hicks's approach to the determination of the interest rate was followed by Keynesian economists like Kaldor (1939; see especially pp. 13-14) and Kalecki ([1943] 1991, pp. 138-39). ${ }^{2}$ According to Hicks (1937, p. 154), the demonstration of the interest rate minimum is "so important that I shall venture to paraphrase the proof, setting it out in a rather different way from that adopted by Mr. Keynes."

If the costs of holding money can be neglected, it will always be profitable to hold money rather than lend it out, if the rate of interest is not greater than zero. Consequently the rate of interest must always be positive. In an extreme case, the shortest short-term rate may perhaps be nearly zero. But if so, the long-term rate must lie above it, for the long rate has to allow for the risk that the short rate may rise during the currency of the loan, and it should be observed that the short rate can only rise, it cannot fall. This does not only mean that the long rate must be a sort of average of the probable short rates over its duration, and that this average must lie above the current short rate. There is also the more important risk to be considered, that the lender on long term may desire to have cash before the agreed date of repayment, and then, if the short rate has risen meanwhile, he may be involved in a substantial capital loss. It is this last risk which provides Mr. Keynes" "speculative motive" and which ensures that the rate for loans of infinite duration (which he always has in mind as the rate of interest) cannot fall very near zero (Hicks, 1937, pp. 154-55; italics in the original). ${ }^{3}$

Hicks deployed in his 1937 demonstration of the floor to the rate of interest the two main elements later developed in his theory of the term structure ([1939] 1946, ch. XI): the notion that the long rate is an average of current and expected short rates (the so-called "expectations theory" of the term structure) and the view that, under the assumption that speculators are averse to risk, they must be paid a liquidity or risk premium to induce them to hold long term securities (the so-called "liquidity-preference theory" of the term structure). Hicks added two important footnotes to the passage quoted above. The first (p. 155, n. 6) note argues that it is unlikely that individuals might interpret the very low short rate as permanent (which would bring the long rate also to a near zero value). Instead, they will interpret it as part of the business cycle and, therefore, be aware that it may possibly rise whether the economy improves (which would increase transactions demand for money) or gets worse (which would increase liquidity preference). Hence, the positive floor to the long rate is a short-run or business cycle phenomenon in Hicks 1937 discussion. The second note (p. 155, n. 7) claims that the "speculative motive" alone cannot account for the system of interest rates, anticipating some elements of his 1939 criticism of Keynes's theory of interest. 
Although Hicks's 1937 demonstration of the interest rate minimum differed from the one found in the General Theory (pp. 201-03), he made clear that it was an elaboration of an original idea by Keynes. The relation between Keynes's and Hicks's formulations is better appreciated with the help of the concept of "elasticity of interestexpectations" introduced in Value and Capital (p. 260). Like the concept of elasticity of price-expectations, it expresses the effect of changes in current short or long rates on their expected values. Two cases must be distinguished, depending on whether interestexpectations mean expectations of short rates or long rates. In the first case, if interestexpectations are rigidly inelastic, a change in the short rate will have almost no effect on the long rate. Hence, the whole adjustment must be made through major changes in the short rate, and "it becomes very easily conceivable that downward adjustments may be necessary on a scale which would involve a negative rate of interest, if interest changes are to restore equilibrium". If interest-expectations are elastic, a reduction in short rates will be followed by lower long rates, which diminishes the danger of repercussions through interest "becoming inoperative because of the minimum below which interest rates cannot fall" ( $p$. 282). Hicks (p. 261) also made the argument in terms of expectations of long rates, which is closer to Keynes. If these expectations are inelastic - that is, if individuals interpret a fall in the long rate as temporary - the current long rate can only be reduced very slightly, since it cannot fall by more than the expected value (at the end of the period) of the long rate multiplied by itself. ${ }^{4}$ As clarified by Kaldor $(1939$, p. 15) in a critical comment on Keynes (1936, pp. 218-19), it is the inelasticity of interest-expectations, not the uncertainty concerning future interest rates, that explains why the demand for liquid funds is highly elastic with respect to the long-term rate, making the long rate stable relatively to the short rate (see also section 4 below).

\section{Keynes versus the "Classics"}

The main reason why Hicks was so careful in his discussion of the existence of a floor to the rate of interest was that he considered it to be "the most important thing in Mr. Keynes' book" (Hicks, 1937, p. 254), a judgment that he repeated in Value and Capital (p. 259) as part of his treatment of absolute instability downwards when prices are falling continuously. Hicks (1950, p. 141) was convinced that the nearly horizontal stretch at the left of the LM curve was "an essential part of Keynes's argument". He later reaffirmed that the individuality of Keynes's theory vis-'a-vis "classical" economics is based on the assumption that there are conditions in which "the interest-mechanism will not work. The special form in which this appears in the General Theory is the doctrine of the floor to the rate of interest - the "liquidity trap' as Sir Dennis Robertson has called it" (1957, p. 279). The IS-LM diagram, according to Hicks (ibid), shows that Keynes and the "classics" are "both of them special cases of something more general...Keynes's model, though an extreme case of the general IS-LM model, is an extreme case that is outsdandingly important." Among pre-Keynesian economics, Hicks (1937, pp. 152-53) distinguished between classical orthodox and the "revised and qualified Marshallian" theories - the former corresponds to the Cambridge quantity theory of money with a given proportion $\mathrm{k}$ between money and nominal income, while the latter (as formulated by F. Lavington and A. C. Pigou) acknowledges that the demand for money depends upon the rate of interest. However, the relevant comparison, according to Hicks, should be between Keynes and the revised theory of later Marshallians that prevailed when the General Theory was written, not between Keynes and the orthodox quantity theory of money.

Hicks's suggested clarification of the difference between Keynes and the qualified classical theory is based on his analysis of the shape of his LL curve (renamed LM by 
Hansen, 1949). The curve will tend to be "nearly horizontal" on the left (because of the floor to the rate of interest discussed above in section 2) and "nearly vertical" on the right, because there is an upper limit to the velocity of money (Hicks, 1937, p. 154). This is illustrated in figure 1, where, as pointed out by Hicks, the LL curve approaches these limits asymptotically. If the IS curve lies to the right, it will cross the upward sloping section of the LL schedule, which means that an increase in investment will raise the rate of interest, as well as income and employment, just like in the revised classical theory. Keynes's theory becomes relevant if, because of a weak inducement to invest or a high propensity to save, equilibrium lies on the left of the LL curve, since, on one hand, the rate of interest is not influenced by real factors, and, on the other, income is not affected by changes in money supply. As stressed by Hicks (p. 155), in this an increase in money supply cannot bring the interest rate down any further - the LL curve shifts to the right, but "the horizontal parts are almost the same", as shown in figure 1. Therefore, Keynes's theory is the "Economics of Depression" (ibid), a judgment that Hicks would repeat on other occasions (see, e.g., 1967a, pp. 156,169$){ }^{5}$

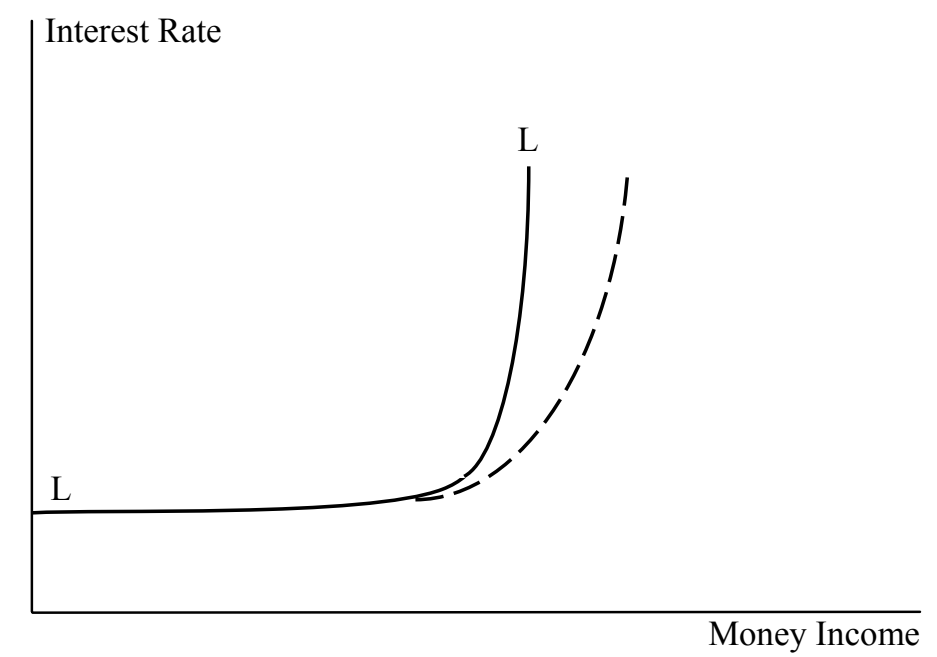

Figure 1. HICKS'S LL CURVE WITH EXOGENOUS MONEY SUPPLY Source: Hicks (1937, p.153).

Hicks's description of the General Theory in terms of the left section of the LL curve was motivated not only by the ineffectiveness of monetary policy in the depression, but also by his attempt to discuss Keynes's "startling conclusion" that an increase in the inducement to invest will not affect the rate of interest, but only employment (Hicks, 1937, p. 152). The point was discussed by Dennis Robertson (1936, pp. 182-83). According to Robertson, Keynes's notion - that the rate of interest does not depend on the demand for loanable funds for use in investment - would only be valid if either "the liquidity schedule proper is perfectly elastic (the curve representing it a horizontal straight line)", or the monetary authority expands the money supply and holds the rate of interest down in face of upward shifts of investment. Hicks had discussed the issue in his 1936 review of the General Theory, but he then focused the argument on the conditions for the operation of the multiplier mechanism, which would bring about an increase in saving and, by that, in the supply of loanable funds (Hicks [1936] 1982, pp. 90-91). ${ }^{6}$ The shift in the argument between the 1936 review and the 1937 IS-LM article may in part reflect Robertson's influence, but one should note that Robertson's description of Keynes's argument in terms of a horizontal LM curve with perfectly elastic demand for money is much closer to Lange's (1938) later formulation than to Hicks's careful discussion of a floor to the rate of interest as the left part of the LM 
curve (see section 4 below). Furthermore, Robertson (p. 183) decided to put aside the case of a horizontal liquidity schedule quoting a passage from the General Theory (p. 207) where Keynes wrote that "whilst this limiting case might become practically important in the future, I know of no example of it hitherto". This is in contrast with Hicks $(1937,1950,1957)$, who, despite Keynes's ambiguity on the relevance of the interest rate minimum (see Laidler, 1999, pp. 258-59), had no doubts about its importance for Keynes's theory.

Despite calling Hicks's attention to the dependency of money demand on the rate of interest in the neo-Marshallian literature (of which he was part, of course), Robertson did not share Hicks's implicit interpretation that the neo-Marshallians realized the full implications of that relation for the analysis of the investment-saving process in general equilibrium. In particular, according to Robertson (1936, pp. 188-190; 1940, pp. 19, 34, 36), the preKeynesian literature did not take into account that an increase in the desire to save, even if it is spent on a purchase of securities, will not bring about an increase in investment in the same proportion. Pre-Keynesian economists overlooked the effect of a fall in the rate of interest (caused by an increase in the demand for securities) on money demand, which interrupts the fall in the rate of interest.

Some part of the additional savings devoted by individuals to the purchase of securities will come to rest in the banking accounts of those who, at the higher price of securities, desire to hold an increased quantity of money. Thus the fall in the rate of interest and the stimulus to the formation of capital will be less than if the [liquidity schedule] were a vertical straight line, and the stream of money income will tend to contract...Liquidity [is] a trap for savings. (Robertson, 1936, pp. 188-89, 190)

Robertson's (1940, pp. 34, 36) phrase "liquidity trap" was originally invented to illustrate the influence of a negatively sloped money demand on the saving-investment process, not a perfectly elastic money demand (which would be just a limiting case of the general Robertsonian liquidity trap). In terms of Hicks's 1937 model, Robertson's trap describes a leftward shift of the IS curve along an upward sloping LM schedule, with an ensuing reduction in income caused by the fact that the rate of interest falls by less than it would fall if the LM were vertical. ${ }^{7}$

The notion that the short-term nominal interest rate cannot fall below zero was occasionally mentioned in the pre-Keynesian literature, usually in connection with the discussion of a deflationary process. This led "classical" authors to recognize the limitations of monetary policy in the depression.

It is in order to counteract the effect of the falling prices that the bankers fix a rate of interest lower than the natural rate by the rate at which prices are believed to be falling... What if the rate of depreciation of prices is actually greater than the natural rate of interest? If that is so nothing that the bankers can do will make borrowing sufficiently attractive. Business will be revolving in a vicious circle...(Hawtrey [1913] 1962, pp. 186-87; italics in the original)

The problem then, from Hawtrey's point of view, is that the (Fisherian) expected real rate of interest is negative, but the bank rate cannot be lower than zero. Similar comments can be found in the 2nd edition of Robertson's ([1928] 1948, p. 177) Money and in Pigou (1933, p. 213). Hawtrey also introduced the notion of a "credit deadlock". According to Hawtrey (1932, p. 172), it may be impossible in the depression to expand the money supply through the banking system due to a crisis of confidence that affects both the demand and supply sides of the credit market. Under these circumstances, open market operations are not able to increase money supply because banks are willing to hold excess reserves rather than lending. As indicated by Wonnacott (1978, pp. 193-94; see also Laidler, 1999, pp. 123, 286), the 
"excess reserve trap" argument advanced by Hawtrey is consistent with the quantity theory of money, since it is not about the ineffectiveness of changes in money supply (as in Hicks's 1937 liquidity trap discussion), but about the difficulty of increasing the money supply through the banking system in the depression. Despite the recognition in the pre-Keynesian literature of limits to monetary policy in the slump, those authors acknowledged that Keynes's (1936, p. 207) suggestion of the possibility that "liquidity preference may become virtually absolute" at a low but positive long rate introduced a new element into the discussion. From this point of view, Hicks's 1937 emphasis on the floor to the long-term rate as a Keynesian contribution is not contradicted by previous discussions of the zero lower bound in the "classical" literature. In contrast with most of that literature (and with part of the recent literature as well, as discussed in section 5 below), it is not based on the assumption of deflationary expectations. ${ }^{8}$

Hicks's 1937 formulation of the floor to the interest rate makes no reference to the banking system, which is also true of the basic version of his IS-LM model as a whole. Nevertheless, Hicks (1937, p. 157) did try to incorporate some features of a banking system by replacing the assumption of a given supply of money by a given "monetary system". As Hicks (1950, pp. 142-43) pointed out later on, this becomes particularly important if under "money supply" one includes bank deposits, since the supply of deposits by the banking system is responsive to interest and income. The new LL curve will not feature in its right part a nearly vertical segment, as the money supply is not fixed anymore. The left part of the curve, on the other hand, will remain the same, which is not clear in Hicks's (1937, p. 157) figure 3. The correct construction of the new LL curve under the assumption of endogenous money supply would be provided by Hicks (1950, p. 141), reproduced below as figure 2. If the monetary system is elastic - meaning that a rise in the rate of interest increases the supply of money - the economy will move from point $\mathrm{P}_{1}$ on curve $\mathrm{L}$ to $\mathrm{P}_{2}{ }_{2}$ on $\mathrm{L}$ ' (with a larger money supply) instead of $\mathrm{P}_{2}$ on the old LL curve. The new LL curve is formed by connecting the dotted points, each one corresponding to a different money supply for a given elasticity of the monetary system (see also Bailey, 1962, ch. 2). In the case of a perfectly elastic monetary system, the adjusted curve would become horizontal at the level of the interest rate minimum, corresponding to a mix of the Keynesian liquidity trap and the Wicksellian pure credit economy (cf. Hicks, 1937, p. 158; 1957, p. 286).

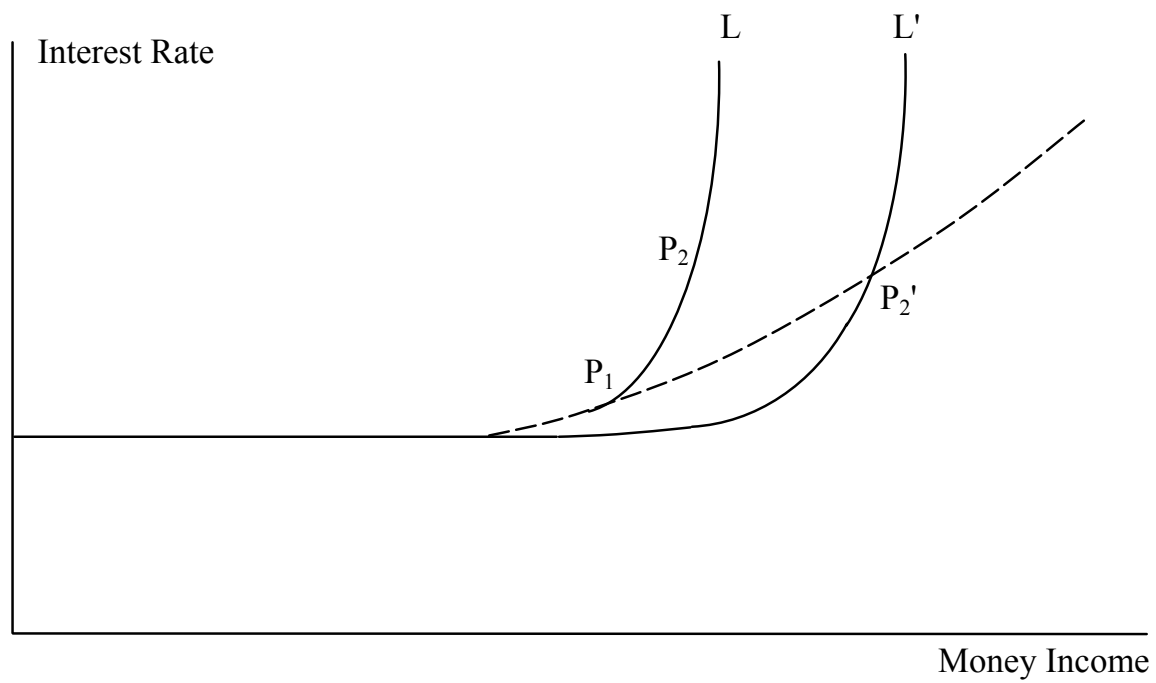

Figure 2. HiCKS's LL CURVE WITH ENDOGENOUS MONEY SUPPLY

Source: Hicks (1950, p.141).

\section{Hansen, Lange and the textbook IS-LM}


Hicks's IS-LM analysis gradually attracted the attention of the profession (Modigliani, 1944; Klein, 1947) until it became the standard representation of "Keynesian economics" after Alvin Hansen $(1949,1953)$ used the model to convey the essentials of macroeconomic theory to students (see Young, 1987, pp. 115-21). Before that, just a year after Hicks (1937), Oskar Lange (1938, p. 12, n. 1) put forward independently an alternative diagrammatic analysis that also focused on the form of the LM function (called by Lange, p. 28, "isoliquidity curve") to establish that Keynes and the "traditional" theory are two special cases of a more general theory (p. 12). Just like Hicks, Lange discussed under what conditions Keynes's claim - that the rate of interest does not react to changes in the marginal efficiency of capital or in the propensity to consume - holds. Lange (pp. 19, 28, 31) argued that Keynes "obviously...must have in mind" the limiting case when the "interest-elasticity of the demand for liquidity is infinite" and the isoliquidity curve "degenerates into a horizontal straight line". Despite apparent similarities with Hicks (1937), one should note that their respective treatments are quite different. In Lange the issue is not the logical existence of a floor to the rate of interest created by a nearly zero short-term rate, but the empirical matter of the value of the interest-elasticity of the demand for money, without any mention of the speculative demand for money (or of the term structure of interest rates for that matter). Accordingly, while Lange described Keynes's case as a completely horizontal LM curve, Hicks distinguished between the different parts of the LM curve. Lange's approach has been adopted by several textbooks, especially when a linear formulation of the IS-LM model is deployed (see, e.g. Dornbusch and Fischer, 1978, ch. 4).

With Franco Modigliani (1944), the Keynes vs. "classics" issue changed from the discussion of the specification of the money demand function to the determination of moneywages in the labour market (see de Vroey, 2000). ${ }^{9}$ In contrast with Hicks (1937), Modigliani used the long-period version of the general classical model with perfectly flexible wages as a benchmark for comparison with Keynes. The floor to the rate of interest is still relevant, but only if the assumption of rigid money-wages is removed from Keynesian theory - as shown by Modigliani (pp. 74-75), if the interest rate is at its minimum level a reduction of moneywages will only affect the price level, with no effect on employment and real wages. Modigliani (p. 77) tended to believe that the (Keynesian) assumption of rigid money-wages has a better empirical basis than the "Keynesian case" of a floor to the rate of interest, which he regarded as a special condition. Again, Hicks $(1937,1957)$ would not disagree with that, but would not accept the description of the "classical" model purely in terms of flexible money-wages.

Modigliani's suggestion that one should draw the line between Keynes and the "classics" according to the assumption about money-wage rigidity was rejected by Lawrence Klein (1947). However, instead of resorting to Keynes's hypothesis of infinite elasticity for money at some low interest rate (for which there was "not sufficient evidence"), Klein (pp. 72 , 85) claimed that the available empirical evidence indicated that the saving and investment functions are interest-inelastic. Accordingly, from Klein's point of view, the core of Keynesian economics is the proposition that there is no positive value of the rate of interest able to equilibrate saving and investment at full- employment income. This is illustrated in figure 3 below, which shows the saving and investment schedules (continuous lines) at full-employment income $\mathrm{Y}_{0}$. Excess saving will be eliminated by a reduction of income to $Y_{1}$, for which saving and investment (dotted lines) can be brought into equality at a positive interest rate. Although Klein distinguished sharply between the interest-inelasticity and the liquidity trap arguments, it is clear enough that they are not entirely disconnected, since his point about the inconsistency between saving and investment arises from the impossibility of reducing the nominal rate of interest below its zero bound. 


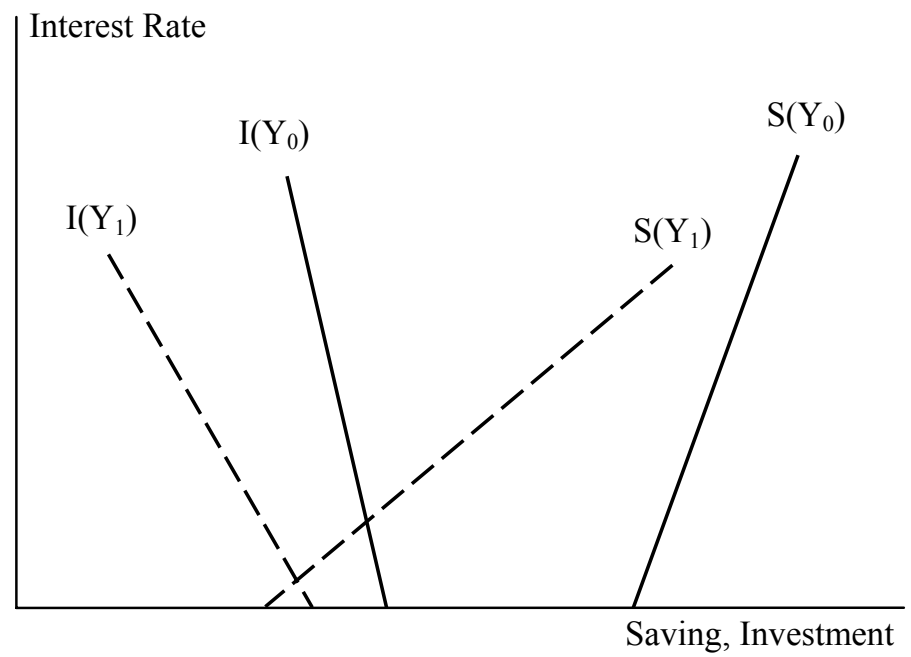

Figure 3. KLEIN'S SAVING-INVESTMENT INCONSISTENCY

Source: Klein (1947, p.85).

Klein's notion of a steep IS function was adapted by Hansen (1949, p. 79), with the suggestion that it becomes interest-inelastic at low income levels only. ${ }^{10}$ As shown in figure 4 below (where income levels, like in Klein, are expressed in real terms), the shape of Hansen's LM is very similar to Hicks's original LL, with its left part approaching asymptotically the interest rate minimum (see also Hansen, 1953, p. 146). In the diagram, $Y_{0}$ represents less than a full-employment, but a high employment real income. An increase in money supply shifts $\mathrm{LM}_{0}$ to $\mathrm{LM}_{1}$, with an expansionist effect since $\mathrm{IS}_{0}$ is interest-elastic. At the point of intersection of the $\mathrm{IS}_{1}$ curve and the $\mathrm{LM}_{0}$ curve, when output is $\mathrm{Y}_{1}$, the IS function is interest-inelastic, while the LM is highly interest elastic. Hansen (p. 80) pointed out that "monetary policy is ineffective" under these circumstances. However, Hansen's explanation of the floor to the rate of interest differs from Hicks's (1937), as well as from Modigliani's (1944). According to Hansen (1949, pp. 64-65; 78; 1953, p.152), the floor to the rate of interest is explained by the fact that the compensation for bearing the risk of a change in (long-term) interest rates approaches zero as the interest rate declines.

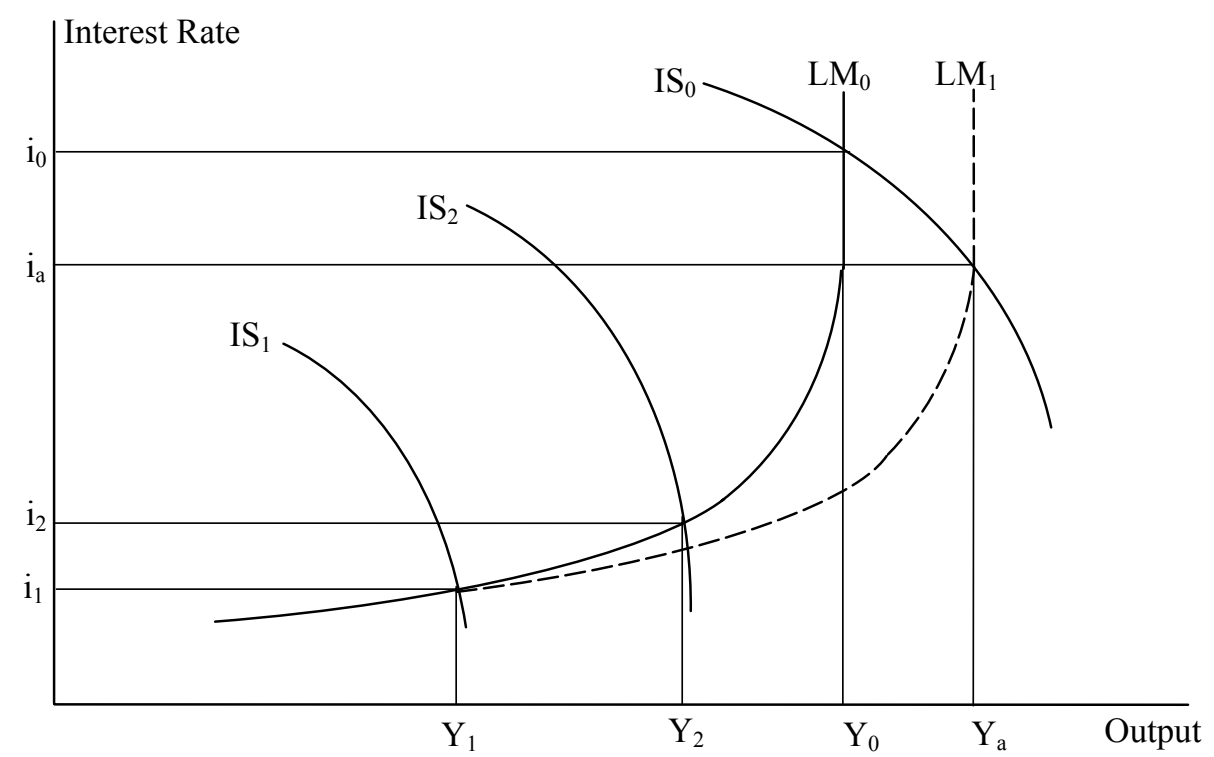

Figure 4. HANSEN'S IS-LM

Source: Hansen (1949, p.79). 
Hansen's 1949 interpretation of the liquidity trap is not based on Keynes's (1936, p. 201) analysis of the behaviour of speculators when the current long-term rate is below what they consider its normal or "safe" value. Instead, Hansen built on another element mentioned by Keynes (pp. 169, 202), that is, the notion that every fall in the interest rate reduces the "insurance premium to offset the risk of loss on capital account". Hansen's diagram was reproduced by Paul Samuelson in the 7th edition of his Economics (1967, p. 331), with the difference that the left stretch of the LM curve approaches zero, instead of a positive (shortterm) interest rate (see figure 5 below). This corresponds to Samuelson's "depression pole", when the LM curve turns horizontal at "vanishingly low interest rates, such as prevailed in the late 1930s".

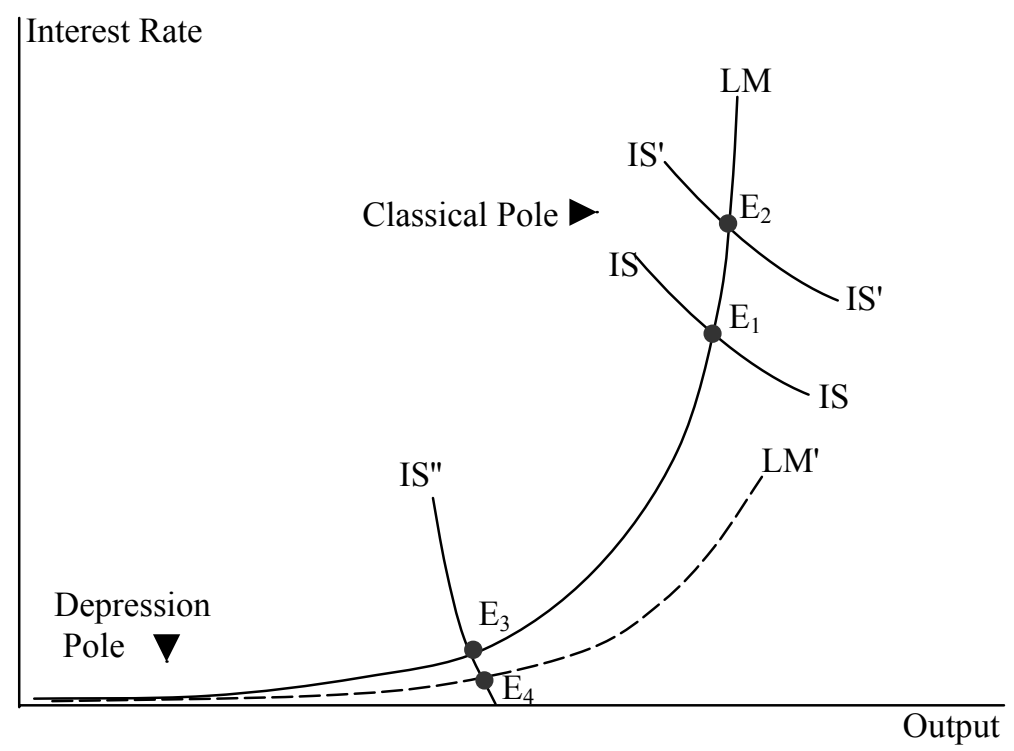

Figure 5. SAMUELSON'S ClASSICAL AND DEPRESSION POLES

Source: Samuelson (1967, p.331).

Despite paying attention to the possibility of a liquidity trap, both Hansen and Samuelson dismissed its association with Keynesian economics. The notion that the IS-LM model represents "Keynesian economics" as a whole is quite clear in Hansen's (1951; 1953, pp. 147-48) assessment that both Keynes's theory - which determines the rate of interest by demand and supply of money - and the "classical" theory of interest - which determines the rate of interest by equilibrium between saving and investment - are indeterminate. According to Hansen, Hicks provided the correct general equilibrium formulation by putting together Keynes and Robertson in the IS-LM model. Hansen's influential identification of IS-LM with Keynesian economics was generally accepted in the literature. The question remained, however, whether money-wage flexibility could be able to bring the economy to its fullemployment output. It was in that context that the liquidity trap continued to attract attention in macroeconomic textbooks. Gardner Ackley (1961, ch. IX) provided a careful textbook discussion of the speculative demand for money and of the liquidity trap as an obstacle to full employment. Although Ackley (p. 363) used intensively the Hicks-Hansen IS-LM model, his presentation of the liquidity trap was based on Keynes's hypothesis of regressive expectations, instead of Hicks's (1937) term structure formulation or Hansen's (1949) risk aversion argument. Keynes's (1936, ch. 15) discussion of the circumstances in which liquidity preference becomes "virtually absolute" at a positive long-term rate of interest was marred by his tendency to interpret that phenomenon as a generalization of his speculative demand for money due to uncertainty as to the future of the rate of interest. However, as explained by Kaldor (1939) and especially by Robinson ([1951] 1952), Keynes's argument 
about the floor to the long rate of interest does not really depend on uncertainty, since it is the very confidence with which speculators believe in the normal price of bonds that makes it difficult to reduce the rate of interest. Furthermore, the "normal" rate is not a constant magnitude, but it falls if the current long rate is continuously lower than the expected rate and if bear speculators are convinced that "the new low rate has come to stay", which may shift the whole LM curve over time, including its horizontal stretch (Robinson, p. 30; Ackley, 1961, pp. 198-201; cf. section 2 above). In that case, both the short and long rates could fall as low as the zero bound. ${ }^{11}$

\section{The recent approach to the liquidity trap}

The Keynesian liquidity trap argument gradually receded into the background in the macroeconomic literature of the 1970s and 1980s. ${ }^{12}$ This is in part explained by the increasing attention devoted to the microfoundations of price and wage rigidity, with the relative marginalization of IS-LM analysis at the time (see Dixon and Gerrard, 2000). Another reason was the long experience with significant inflation rates in Europe, Japan and the United States, accompanied by high nominal interest rates. Hicks (1979, p. 994) remarked at the end of his comments on his contributions to Keynesian economics:

Perhaps I should say something about the 'floor to the rate of interest', which was so important in Keynes's own thinking, and which figured a good deal in my earlier writings on Keynes. One can see why it appeared, in the thirties, to be such an important matter; in the inflationary conditions to which we have now become accustomed, it is irrelevant.

The return of the liquidity trap concept to the research agenda of monetary macroeconomics in the late 1990s reflected changes in the economic environment, with deflationary tendencies in Japan and near price stability in the United States and Europe. From a theoretical perspective, it also reflected the absence of a real balance effect in the new generation of IS-LM models based on optimizing behaviour. Moreover, the criticism of the traditional Keynesian approach to the demand for money as well as the focus on an economy with multiple financial assets, brought monetary theory closer to Hicks's (1935, 1937, [1939] 1946) treatment. The term-structure of interest rates (also called the "yield curve") is prominent in Olivier Blanchard's (1997, ch. 9) macroeconomics textbook. Blanchard (p. 193) draws an IS-LM diagram with the short-term rate on the vertical axis and, consequently, a very steep IS curve. An expansionary monetary policy, for given expectations of future interest rate or future output and assuming that the original short-term rate is positive, shifts the LM curve downwards, with a small effect on current output. If the expansion in money supply is accompanied by an anticipation of a lower interest rate in the future the IS curve will shift to the right as well, with a large impact on output. Blanchard's (1997) emphasis on the term-structure is fully consistent with Hicks's original insight, as discussed above in section 2 .

The new generation of optimizing IS-LM models (McCallum, 1989, pp. 102-07; Walsh, 1998, pp. 202-11; Krugman, 1998, pp. 142-49; McCallum and Nelson, 1999) usually assumes, for mathematical tractability, that bonds last for just one period. The money demand function is specified in terms of a model of money as a medium of exchange (money-in-the utility-function, shopping time or cash-in-advance models), with the general result that the (short-term) nominal interest rate is positive only if money yields liquidity services (Walsh, pp. 57, 103). This is a formalization of Hicks's insight in ch. XIII of Value and Capital (see section 2). Whether the nominal short-term rate can be pushed to zero or to a small positive number depends on the specification of the utility function and of the role of money in the economy. If money has no storage costs and there is a finite level of money 
balances at which there is satiation with the transaction services of money, it will be possible to reduce the nominal rate all the way to zero, as in Krugman's (1998) cash-in-advance model (see also McCallum, 2000, pp. 875-76). Otherwise, there will be a liquidity trap at a low positive short-term nominal interest rate. As discussed above, Hicks and his followers (Kaldor, 1939; Kalecki, 1943; Modigliani, 1944) assumed that the lower bound to the short nominal rate was generally slightly above zero, but this makes no real difference for the analysis of a liquidity trap.

Apart from the specification of the LM curve as a function of the (short-term) nominal rate of interest, another important feature of the optimizing IS-LM models is the assumption that the IS curve is a function of the expected (long-term) real interest rate, that is, the nominal rate minus the rational expectation of the inflation rate. The notion that nominal rates matter for the LM, while real rates are relevant for the IS curve was firstly advanced by Martin Bailey (1962, pp. 50-51) in his discussion of inflationary equilibrium, but it became part and parcel of the textbook literature only gradually (see, e.g., McCallum, 1989, pp. 112-117; Blanchard, 1997, pp. 139-42). Hicks ([1939] 1946) was, of course, aware of the distinction between real and nominal interest rates, which had been introduced earlier on by Irving Fisher. ${ }^{13}$ However, in the framework of Value and Capital (and of the 1937 ISLM article), the assumption of unity elasticity of price-expectations was enough to yield Hicks's instability results; price-expectations greater than unity could accentuate but in no way change the essence of Hicks's argument, just like in the Wicksellian cumulative process of price change. Moreover, if the central bank follows a Wicksell-Taylor interest rate feedback rule - whereby the short-term nominal rate is set as an increasing and nonnegative function of the inflation rate - it can be shown that deflationary expectations, together with a lower bound to the nominal interest rate, may lead to a self-fulfilling deflationary spiral than cannot be avoided by monetary policy (see Benhabib, Schmitt-Grohé and Uribe, 2002). ${ }^{14}$

Another factor that may bring about a liquidity trap in recent discussion is the possibility that the Wicksellian "natural rate of interest" - that is, the rate of interest that equilibrates saving and investment at full-employment income - is negative (Krugman, 1998; 2000a). As discussed in section 4 above, Klein (1947) associated that possibility with the interest-inelasticity of saving and investment. In the modern framework, the natural rate of interest, as decided by the rate of time preference, will be negative if the marginal utility of consumption in the next period is greater than in the current period, which will happen if people expect their income to fall in the future (cf. Krugman, 1998, p. 150). Alfred Marshall ([1890] 1990, pp. 192-93) had entertained the possibility of a negative natural rate, but apparently did not realize that, in a monetary economy, the actual rate of interest could never be lower than zero. While for Pigou (1943) the economy will eventually converge to its fullemployment growth path through the effect of falling prices on shifting the saving function (the so-called "Pigou effect"), Krugman argues that a fall in current prices will bring the economy back to full-employment equilibrium only if it represents an increase in the ratio between the expected future and the current price levels and, by that, a reduction in the expected real rate of interest to the level of the negative natural rate of interest.

The real balance effect is not generally part of the Euler condition used in deriving the IS function in recent optimizing IS-LM models. As discussed by McCallum (2000, pp. 882-83) and Woodford (2002, section 3.1), a real balance effect would arise if real balances entered the representative agent's utility function and this function was nonseparable with a positive cross-derivative between consumption and real balances. However, even if the real balance effect is present in the IS function, this effect vanishes when the short-term nominal interest rate falls to its lower bound. As explained by Woodford (2002, section 4.2), additional real balances affect the marginal utility of expenditure only to the extent they can 
reduce the short-term nominal rate, which indicates the value of further reduction in transactions frictions from holding more wealth in money form. Hence, the real balance effect, as a liquidity effect, will not work under liquidity trap conditions (see also Rabin and Keilany, 1986-87, for a first formulation of this criticism). Nevertheless, the issue has not yet been settled in the literature, since the real balance effect might still work as a wealth effect (instead of as a liquidity effect) if consumption is formalized as function of permanent income and population is growing, so that money can be treated as net wealth (see Ireland, 2001). ${ }^{15}$

\section{Krugman, expectations and the IS-LM model}

Krugman's $(1998,2000$ a) discussion of the liquidity trap concept is particularly relevant for the purposes of the present paper, since he explicitly presents it as part of an intended reformulation of Hicks's original IS-LM model (on Krugman's argument see also Kregel, 2000 and Sumner, 2002). Krugman (1998, pp. 138-39, 142-45; 2000a, pp. 224-27) put forward a simple rational expectation model of a representative agent that maximizes her intertemporal utility function and demands money according to a cash-in-advance constraint in an endowment economy. Under the assumption that there is no uncertainty and that the nominal rate of interest on one-period bonds is positive, the cash-in-advance constraint will be binding. The representative agent will hold just enough cash to make her consumption purchases, which implies a strictly proportional relationship between the money supply and the price level 'a la quantity theory of money: $\mathrm{P}=\mathrm{M} / \mathrm{y}$, where $\mathrm{y}$ is the output level, equal to consumption. This relationship is represented by the vertical line MM in figure 6 below, which describes equilibrium in the market for money - Krugman's LM curve. The IS curve is obtained from the equilibrium in the market for goods, derived by Krugman from the Euler equation for consumption: $(1+i)\left(P_{t} / P_{t+1}\right)=(1 / D)\left(y_{t+1} / y_{t}\right)^{\rho}$, where $D$ and $\rho$ stand for the discount factor and relative risk aversion, respectively. This equation is illustrated by the curve CC in figure 6. The price level in the next period $\left(\mathrm{P}_{\mathrm{t}+1}\right)$ is determined by $\mathrm{M}_{\mathrm{t}+1}$ and $\mathrm{y}_{\mathrm{t}+1}$, which are assumed to be given constants. Hence, a rise in the current price level generates expected deflation and a lower nominal rate of interest, for a given real (or "natural") interest rate, which explains the inverse relation illustrated by curve CC - Krugman's IS curve.

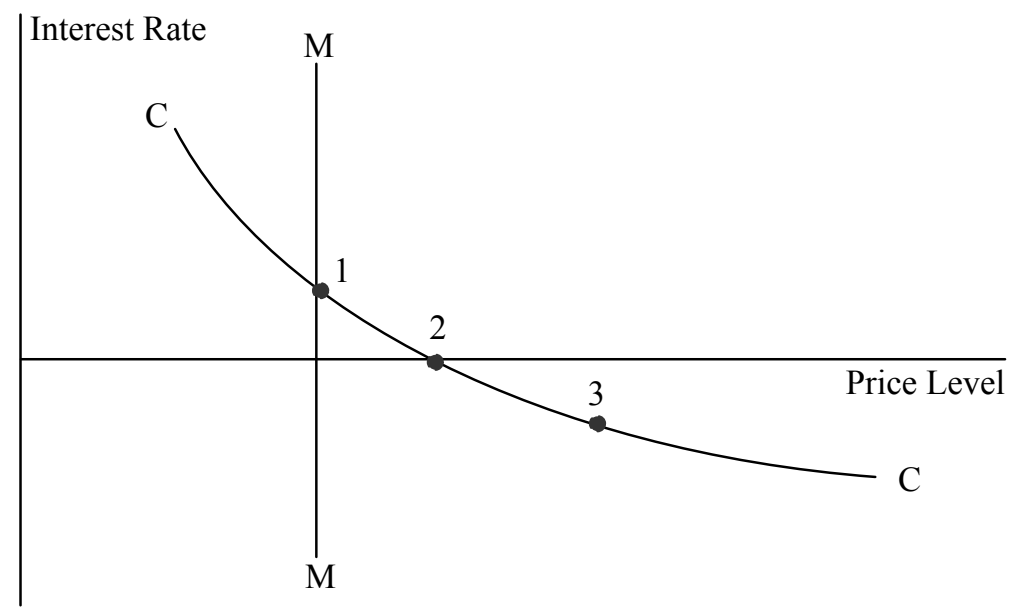

Figure 6. KRUGMAN'S IS-LM WITH FLEXIBLE PRICE LEVEL

Source: Krugman (1998, p.145).

The representation of equilibrium in the markets for money and for goods in a flexible price economy in (i, P) space - instead of the (i, y) space of the usual IS-LM diagram - was originally advanced by Patinkin ([1956] 1965, p. 233; see also Krugman, 2000b). In terms of 
Hicks's original framework, Krugman's assumption that the future expected price level $\left(\mathrm{P}_{\mathrm{t}+1}\right)$ remains constant when the current price level $\left(\mathrm{P}_{t}\right)$ changes means that the elasticity of priceexpectations is zero. As discussed in section 2 above, this implies, according to Hicks, that the system can be stabilized through intertemporal substitution, which is exactly Krugman's conclusion. Krugman's initial focus on a flexible price economy is necessary in order to explain under what conditions the central bank may loose its ability to control the price level. This can be illustrated in figure 6 by expanding current money supply - for a given long-run money supply and expected price level in future periods - until the MM and CC curves intersect at point 3 , with a negative nominal interest rate. In this context, a liquidity trap arises if the economy is beset by deflationary expectations that shift the CC curve to the left or if the equilibrium natural or real interest rate is negative because of the time preferences of individuals. Krugman (1998, [1999] 2000, 2000a) discusses mainly the last factor, which he believes can be applied to the Japanese economy in the late 1990s (see also Kuttner and Posen, 2001). Under these circumstances, the current price level will fall in relation to the expected future price level, with an ensuing reduction of the real expected rate of interest to its negative equilibrium level. Again, it is Krugman's assumption that the expected price level is given - in contrast with Hicks's unity elasticity of price-expectations - that is behind the equilibration mechanism that prevents a cumulative price fall in the liquidity trap. Hicks ([1939] 1946, pp. 271, 298) was aware that "people's sense of normal prices" might counteract the initial effects of the unity elasticity of price-expectations and stabilize the economy in the depression.

Krugman next investigates the role of monetary policy in a liquidity trap under the assumption that the price level in the current period is predetermined and that the consumption good is produced, instead of the price flexible economy with a given endowment discussed so far. In this case, output is determined by consumption demand, which is a decreasing function of the interest rate. The equation for the IS curve is now given by $y=y_{t+1}\left(P_{t+1} / D P_{t}\right)^{1 / p}(1+i)^{-1 / \rho}$, which is drawn as curve CC in the $(i, y)$ space in figure 7 below. Once again, expansionary money supply will not be able to increase output beyond point 2, which is supposed to be below its full-employment level illustrated by point 3 . Nevertheless, in Krugman's framework, this is only true if monetary expansion is seen by individuals as transitory, that is, if the future money supply is held constant. Even if the nominal rate of interest is zero, an increase in the money supply perceived to be permanent will raise current prices in the flexprice model, or output in the sticky price model, since the $\mathrm{CC}$ curve in figures 6 and 7 will shift upwards when individuals expect higher prices in the future. The upshot is that the liquidity trap concept involves now a "credibility problem": monetary policy is ineffective only if people do not believe that monetary expansion will be kept in the future (Krugman, 1998, pp. 142, 161).

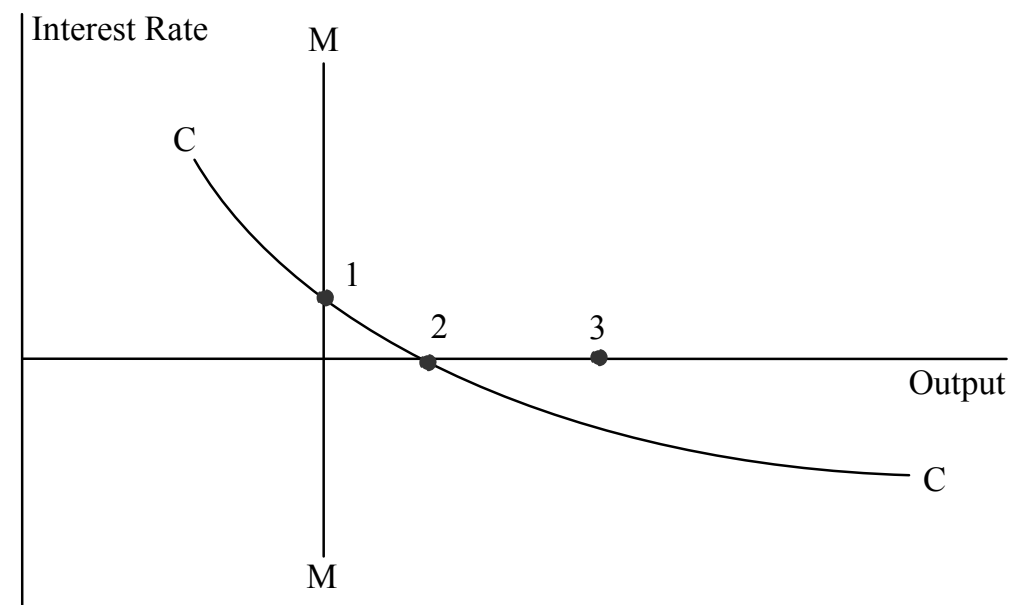

Figure 7. KRUGMAN'S IS-LM WITH PREDETERMINED PRICE LEVEL

Source: Krugman (1998, p. 149). 
The notion that expected inflation could provide a way out of the impasse posed by a negative natural rate of interest can be found already in Bailey (1962, p. 101). Bailey dismissed its practical relevance on the grounds that "there is nothing to assure that such expectations will develop...there is no reason in principle why [expectations] should be so accommodating as to make equilibrium possible". Krugman, though, claims that inflationary expectations can be generated by the perception by forward looking consumers of the future path of money supply. The assumption of forward looking expectations has implications not just for the liquidity trap concept, but for the interpretation of the IS-LM model as a whole. Indeed, as pointed out by Axel Leijonhufvud (1983, 1987), traditional IS-LM analysis is based on the notion that disturbances that shift one of the curves will not at the same time affect the position of the other curve, which is not true under a rational expectations equilibrium. In particular, an anticipated monetary impulse will shift both IS and LM schedules, with the implication that the interest-elasticity of the two curves is largely irrelevant for the monetary transmission mechanism in general and for the liquidity trap in particular. The view that a permanent increase the money supply - as opposed to a temporary one - will shift both IS and LM curves to the right is conspicuous in the open macroeconomic model deployed by Krugman and Obstfeld (1994, pp. 392, 456, 474). That notion has been applied to the discussion of the liquidity trap concept in the 6th edition of the book, which has repeated Krugman's 1998 argument (see Krugman and Obstfeld, 2003, pp. 499-501) in the context of an open economy. Krugman's reinterpretation of the liquidity trap as a credibility problem has also made its way into recent macroeconomic textbooks (see, e.g., Gordon, 2000, pp. 135-38; Mankiw, 2003, p. 303).

The role of expectations in Keynes's theory and in the IS-LM model was an object of concern for Hicks since his 1936 book review. Although Hicks hailed Keynes's notion that short-period equilibrium depends on the state of expectations, he was critical of the assumption that such expectations could be treated as given when economic policy changes. In Value and Capital, expectations of price are determined by autonomous changes in the state of the "news" and by the elasticity of price-expectations (p. 204). Hicks ([1939] 1946, pp. 277-79) showed how an autonomous rise in price-expectations will shift demand in favour of current commodities at the expense of securities or money, with an increase in current prices. He did not apply that to the discussion of the liquidity trap concept, though, except indirectly by calling attention to the role of "normal prices" as a stabilizer at the bottom of the depression. The analysis of the influence of expectations of future monetary policy on the determination of the current long-term interest rate was not extended by Hicks to the determination of the price level (It is worth noting that Dennis Robertson had discussed in the 1920s the relation between price level expectation and future money supply; see Boianovsky and Presley, 2002). Later on Hicks (1969, p. 313) would point out that "one can grant that there exists an irrational element in expectations (the element of which Keynes made so much) without conceding that they are so irrational as to be random - and therefore incapable of being moulded, at least to some extent, by policy".

\section{Concluding Remarks}

Hicks's formulation of a long-term interest rate minimum in the 1937 IS-LM article was based on his theory of the determination of the short-term rate by the marginal value of liquidity and of the long rate by the term structure, plus the double assumption of elastic 
price-expectations and inelastic interest-expectations. The theory of interest developed in Value and Capital has provided the foundation for much of the modern approach to the determination of interest rates, which helps to explain why Hicks's 1937 presentation of the liquidity trap argument is in many ways closer to the recent discussion than Keynes's or the traditional textbook version built on Hansen or Lange. Despite similarities between Hicks's original treatment and recent literature, it should be noted that Hicks's 1937 emphasis on a positive floor to the long-term rate of interest (following Keynes's perspective) has not been shared in the theoretical discussion triggered by the Japanese depression of the late 1990s. Instead, the focus is on the lower bound to the short-term interest rate used as an instrument of monetary policy by the central bank. Accordingly, the rate of interest determined in recent optimizing IS-LM models is the rate on a one-period bond. Although it is occasionally mentioned (see, e.g., Krugman, 1998, p. 146) that in a liquidity trap the interest rate is zero (or nearly so) on short-period bonds only, this is not generally incorporated into recent models. In any event, the implicit justification for such an approach is that long-term interest rates are also bound as soon as the short rates have hit their (near) zero lower bound, which is not inconsistent with Hicks's 1937 insight. As put by Hicks (1969, p. 314), the "famous trouble of the "floor' to the rate of interest" is "one of the legacies to "modern' Keynesian economics of Keynes's preoccupation with the long rate". However, a liquidity trap may also arise in IS-LM models where the short rate is used as the representative interest rate; in this case the floor will be (near) zero. By focusing analytically on the short rate minimum, the recent literature is led to stress deflationary expectations (just like some pre-Keynesian authors) or a negative natural rate of interest as necessary conditions for the emergence of a liquidity trap. Both elements are sufficient but not necessary conditions for the 1937 demonstration of a Hicksian liquidity trap. In the same vein, the possibility of a liquidity trap in recent discussion is not related to the interest-elasticity of money demand or to the slope of the LM curve, since, by definition, money and bonds become perfect substitutes when the short rate hits its (near) zero lower bound. This is illustrated by Krugman's formulation of a vertical LM curve to investigate the liquidity trap concept.

The revival of interest in the notion of a liquidity trap has not been generally motivated - in contrast with the discussion by Hicks, Lange and (to a lesser degree) Modigliani, Hansen and traditional textbooks - by an attempt to use the IS-LM model to distinguish between Keynesian and classical economics. We have seen that the liquidity trap concept played a key role in Hicks's IS-LM exercise in part because of his encompassing description of neo-Marshallian monetary theory, differently from the original meaning of a liquidity trap as conceived by Robertson. Hicks's suggestion that the General Theory is the economics of depression has been controversial in macroeconomic theory, but it did bring to the fore the idea of demand failures that cannot be corrected by cutting the interest rate all the way to its lower bound. This is the aspect of the liquidity trap concept that has attracted most attention recently (see, e.g., Krugman, [1999] 2000, ch. 9). The reexamination of the liquidity trap idea has been done in the context of optimizing IS-LM models, with emphasis on the expectations formation mechanism. Hicks was aware that the notion of a liquidity trap - and of aggregate instability in general - depends heavily on the assumption about priceexpectations. The instability results of his classic 1939 book and of the 1937 article are built on the assumption of unity (or higher) elasticity of price-expectations. Hicks's notion of elasticity of price-expectations (that is, adaptative expectations) has been replaced in the new generation of IS-LM models by forward-looking expectations, which has led to new insights into the liquidity trap concept.

\section{Notes}


Financial support from CNPq (Brazilian Research Council) is gratefully acknowledged.

1. The association between instability and unity elasticity of price-expectations was first made by Knut Wicksell ([1898] 1936) in his famous discussion of the cumulative process of price change.

2. Hicks's notion that the short-term nominal interest rate becomes zero in the absence of transaction frictions was criticized by Modigliani (1944, pp. 82-86) and Patinkin ([1956] 1965, pp. 109-10), on the grounds that the consequence of an increased liquidity of securities is not a lowered rate of interest, but a decreased use of money as a medium of exchange. However, Hicks's result has been vindicated by recent monetary models (see Walsh, 1998, chapters 2 and 3 ).

3. Haberler ([1937] 1946, p. 220) has been one of the few commentators to notice the similarity between that passage and ch. XI of Value and Capital.

4. This comes from Hicks's ([1939] 1946, pp. 149, 261, n. 2) formula that the net yield obtainable by investing in long-term securities for a given period is $R+(R / R$ ') - 1, where $R$ is the current long-term rate and $R^{\prime}$ stands for the rate expected to rule at the end of the period. Since that expression is necessarily positive, $R$ must be higher than $R^{\prime}\left(1+R^{\prime}\right)$, or approximately, $\mathrm{R}>\mathrm{R}$ '(1 - R'), which gives the maximum possible fall in the current long rate. It corresponds to Keynes's (1936, p. 202) well-known proposition that a liquidity trap will occur if investors expect long term rates to rise by more than the square of the current long interest rate (see also Kregel, 2000, p. 53).

5. The notion that Keynes's General Theory was designed to supply a theory for the Great Depression, despite the absence of explicit references to that episode in the book, has been forcefully argued by Robert Skidelsky (1992, pp. 440-41).

6. See also Kregel (2000, pp. 42-47). Kregel, however, wrongly imputes to Hicks (1937) the argument that the horizontal stretch of the LM curve is based on the assumption of a high elasticity of supply of consumption goods or of money.

7. It was in his review of Robertson's 1940 Essays that Hicks (1942, p. 56) used for the first time Robertson's phrase "liquidity trap for savings".

8. The deflationary process is important, however, to explain what Hicks ([1939] 1946, pp. 264-65) called "depression psychology", provoked by the impact of unexpected falling prices on the real value of debt and the ensuing "fear of bankruptcy".

9. Modigliani's (1944) emphasis on the labour market as the dividing line between Keynes and the "classics" had been anticipated by Champernowne's (1936) argument that, in Keynes's framework, money-wages do not adjust quickly to changes in prices because workers' price expectations are adaptative (see Boianovsky, 2004). Champernowne's formalization of the differences between Keynes and the "classics" represented the main alternative at the time to Hicks's IS-LM approach. Instead of Hicks's general equilibrium with simultaneous equations, Champernowne stressed the distinct causality structures of Keynes's and "classical" theories.

10. Hansen (1949, pp. 79-80) sometimes associated the interest-inelasticity of the IS curve in the depression to capital saturation, but this is imprecise, since the capital stock is a given constant in the IS-LM model.

11. The fall in the long-term interest rate in Great Britain in the mid 1930s was explained by Hicks (1967a, pp. 96-97) along similar lines.

12. Tobin $(1980$, p. 5) was an exception to this tendency. Tobin explained a liquidity trap along Hicksian lines, that is, the fact that "the absolute floor for nominal interest rates is zero", together with the notion that "long term rates...would be held above zero by expectations...that short rates will rise from rock bottom in future". 
13. As pointed out by Hicks ([1939] 1946, pp. 119, 160; italics in the original) "it is only in a stationary state that actual prices do not need to be distinguished from expected prices; ...that money rates of interest do not need to be distinguished from real rates of interest, and interest rates for one period of lending from interest rates for another." It should be noted that Hicks's proposition about zero interest rate in the absence of transaction frictions applies to the nominal, not to the natural or real rate.

14. The modern notion of a liquidity trap can also be applied if the usual LM curve (based on the assumption that the central bank targets the money supply) is replaced by the assumption that the central bank follows an interest rate rule instead (see Romer, 2000). In this case, the zero lower bound puts a floor on the nominal interest rate that can be set by the central bank (although not necessarily on the real expected interest rate, if the expected rate of change in prices is positive). It is worth noting that Romer's curve differs from Hicks's suggestion of an elastic LM curve discussed above, since Hicks had in mind reactions by the private banking system to changes in the interest rate (just like in Wicksell), not an interest rate rule set by a central bank.

15. Before the revival of interest in the liquidity trap, the notion of a zero interest rate was usually associated in monetary economics with Milton Friedman's (1969, ch. 1) proposition that only monetary policies that generate a zero nominal interest rate will lead to satiation in money demand and, therefore, to optimality. The contrast between the optimality of zero nominal interest in Friedman's framework and the depression scenario of the recent liquidity trap literature has been discussed by Uhlig (2000).

\section{References}

Ackley, G. 1961. Macroeconomic Theory. New York: Macmillan.

Bailey, M.J. 1962. National Income and the Price Level. New York: McGraw-Hill.

Benhabib, J., S. Schmitt-Grohé and M. Uribe. 2002. Avoiding Liquidity Traps. Journal of Political Economy. 110 (3): 535-63.

Blanchard, O. 1997. Macroeconomics. New Jersey: Prentice Hall.

Boianovsky, M. 2004. Some Cambridge Reactions to the General Theory: David Champernowne and Joan Robinson on Full Employment. Cambridge Journal of Economics.

Boianovsky, M. and J. Presley. 2002. On the Natural Rates of Unemployment and Interest: The Robertson Connection. Loughborough University. Department of Economics. Working Paper 8/2002.

Champernowne, D.G. 1936. Unemployment, Basic and Monetary: The Classical Analysis and the Keynesian. Review of Economic Studies. 3: 201-16.

Colander, D. and E. Gamber. 2002. Macroeconomics. New Jersey: Prentice Hall.

de Vroey, M. 2000. IS-LM `a la Hicks versus IS-LM `a la Modigliani. History of Political Economy. 32 (2): 293-316.

Dixon, H. and B. Gerrard. 2000. Old, New and Post Keynesian IS-LM Framework: A Contrast and Evaluation. In W. Young and B. Zilberfarb (eds). IS-LM and Modern Macroeconomics. Boston: Kluwer, ch. 1.

Dornbusch, R. and S. Fischer. 1978. Macroeconomics. Tokyo: McGraw-Hill.

Friedman, M. 1969. The Optimum Quantity of Money and Other Essays. Chicago: Aldine.

Froyen, R. 2002. Macroeconomics - Theories and Policies. 7th edition. New Jersey: Prentice Hall.

Fuhrer, J. and B. Madigan. 1997. Monetary Policy When Interest Rates Are Bound At Zero. Review of Economics and Statistics. 79 (4): 573-85.

Gärtner, M. 2003. Macroeconomics. London: Financial Times/Prentice Hall.

Gordon, R. 2000. Macroeconomics. 8th edition. Boston: Addison-Wesley. 
Haberler, G. [1937] 1946. Prosperity and Depression. New York: United Nations.

Hansen, A. 1949. Monetary Theory and Fiscal Policy. New York: McGraw-Hill.

Hansen, A. 1953. A Guide to Keynes. New York: McGraw-Hill.

Hawtrey, R.G. [1913] 1962. Good and Bad Trade. New York: A.M. Kelley.

Hawtrey, R.G. 1932. The Art of Central Banking. London: Longman.

Hawtrey, R.G. [1937] 1952. Capital and Employment. 2nd edition. London: Longmans, Green.

Hicks, J. 1935. A Suggestion for Simplifyng the Theory of Money. Economica. 2(Feb): 1-19. Hicks, J. [1936] 1982. Mr. Keynes' Theory of Employment. Economic Journal. 46 (June): 238-53. As reprinted in J. Hicks (1982), pp. 84-93.

Hicks, J. 1937. Mr. Keynes and the "Classics": A Suggested Interpretation. Econometrica. 5 (April): 147-59.

Hicks, J. [1939] 1946. Value and Capital. 2nd edition. Oxford: Clarendon Press.

Hicks, J. 1942. The Monetary Theory of D.H. Robertson. Economica. 9 (Feb): 53-57.

Hicks, J. 1950. A Contribution to the Theory of the Trade Cycle. Oxford: Clarendon Press.

Hicks, J. 1957. A Rehabilitation of "Classical" Economics? Economic Journal. 67 (June): 278-89.

Hicks, J. 1967a. Critical Essays in Monetary Theory. Oxford: Clarendon Press.

Hicks, J. 1969. Automatists, Hawtreyans, and Keynesians. Journal of Money, Credit and Banking. 1 (Aug): 307-17.

Hicks, J. 1979. On Coddington's Interpretation: A Reply. Journal of Economic Literature. 17 (Sept): 989-95.

Hicks, J. 1982. Money, Interest and Wages. Cambridge (Mass.): Harvard University Press. Ireland, P. 2001. The Real Balance Effect. NBER Working Paper 8136.

Kaldor, N. 1939. Speculation and Economic Stability. Review of Economic Studies. 7 (1): 127.

Kalecki, M. [1943] 1991. Studies in Economic Dynamics. In J. Osiatynsky (ed). Collected Works of Michal Kalecki, vol. II. Oxford: Clarendon Press.

Keynes, J.M. 1936. The General Theory of Employment, Interest and Money. London: Macmillan.

Klein, L. R. 1947. The Keynesian Revolution. New York: Macmillan.

Kregel, J. 2000. Krugman on the Liquidity Trap: Why Inflation Won't Bring Recovery to Japan. Economia. 1 (1): 39-58.

Krugman, P. 1998. It's Baaack: Japan's Slump and the Return of the Liquidity Trap. Brookings Papers on Economic Activity. no. 2: 137-205.

Krugman, P. [1999] 2000. The Return of Depression Economics. 2nd edition. London: Penguin Books.

Krugman, P. 2000a. Thinking About the Liquidity Trap. Journal of the Japanese and International Economics. 14 (Dec): 221-37.

Krugman, P. 2000b. How Complicated Does the Model Have To Be? Oxford Review of Economic Policy. 16 (4): 33-42.

Krugman, P. and M. Obstfeld. 1994. International Economics. 3rd edition. New York: HarperCollins.

Krugman, P. and M. Obstfeld. 2003. International Economics. 6th edition. Boston: AddisonWesley.

Kuttner, K. and A. Posen. 2001. The Great Recession: Lessons for Macroeconomic Policy from Japan. Brookings Papers on Economic Activity. no.2: 93-185.

Laidler, D. 1999. Fabricating the Keynesian Revolution. Cambridge: Cambridge University Press. 
Lange, O. 1938. The Rate of Interest and the Optimum Propensity to Consume. Economica. 5 (Feb): 12-32.

Leijonhufvud, A. 1983. What Was the Matter with IS-LM? In J.-P. Fitoussi (ed). Modern Macroeconomic Theory: An Overview. Oxford: Basil Blackwell.

Leijonhufvud, A. 1987. IS-LM Analysis. In J. Eatwell, M. Milgate and P. Newman (eds). The New Palgrave - A Dictionary of Economics, vol. 2, pp. 1002-04. London: Macmillan.

Mankiw, N.G. 2003. Macroeconomics. 5th edition. New York: Worth Publishers.

McCallum, B.T. 1989. Monetary Economics. New York: Macmillan.

McCallum, B.T. 2000. Theoretical Analysis Regarding a Zero Lower Bound on Nominal Interest Rates. Journal of Money, Credit and Banking. 32 (4): 870-904.

McCallum, B.T. and E. Nelson. 1999. An Optimizing IS-LM Specification for Monetary Policy and Business Cycle Analysis. Journal of Money, Credit and Banking. 31 (3): 296-316. McKinnon, R. and K. Ohno. 1997. Dollar and Yen - Resolving Economic Conflict Between the United States and Japan. Cambridge (Mass.): MIT Press.

Modigliani, F. 1944. Liquidity Preference and the Theory of Interest and Money. Econometrica. 12 (1): 45-88.

Patinkin, D. [1956] 1965. Money, Interest, and Prices. 2nd edition. New York: Harper \& Row.

Pigou, A.C. 1933. The Theory of Unemployment. London: Macmillan.

Pigou, A.C. 1943. The Classical Stationary State. Economic Journal. 53 (Dec): 343-51.

Rabin, A. and Z. Keilany. 1986-87. A Note on the Incompatibility of the Pigou Effect and a Liquidity Trap. Journal of Post Keynesian Economics. 9 (2): 291-96.

Robertson, D.H. [1922, 1928] 1948. Money. London: Nisbet.

Robertson, D.H. 1936. Some Notes on Mr. Keynes' General Theory of Interest. Quarterly Journal of Economics. 51 (Nov): 168-91.

Robertson, D.H. 1940. Essays in Monetary Theory. London: P.S. King.

Robinson, J. [1951] 1952. The Rate of Interest. Econometrica. 19 (2): 92-111. As reprinted in J. Robinson (1952).

Robinson, J. 1952. The Rate of Interest. London: Macmillan.

Romer, D. 2000. Keynesian Macroeconomics Without the LM Curve. Journal of Economic Perspectives. 14 (2): 149-69.

Samuelson, P.A. 1967. Economics. 7th edition. New York: McGraw-Hill.

Skidelsky, R. 1996. The Influence of the Great Depression on Keynes's General Theory. History of Economics Review. 25 (Winter-Summer): 78-87.

Sumner, S. 2002. Some Observations on the Return of the Liquidity Trap. Cato Journal 21 (3): 481-90.

Svensson, L. 2001. The Zero Bound in an Open Economy: A Foolproof Way of Escaping from a Liquidity Trap. Monetary and Economic Studies, special edition. Feb: 277-321.

Tobin, J. 1980. Asset Accumulation and Economic Activity. Oxford: Basil Blackwell.

Uhlig, H. 2000. Should We Be Afraid of Friedman's Rule? Journal of the Japanese and International Economics. 14 (Dec): 261-303.

Walsh, C.E. 1998. Monetary Theory and Policy. Cambridge (Mass.): MIT Press.

Wicksell, K. [1898] 1936. Interest and Prices. Translated by R.F. Kahn. London: Macmillan. Wonnacott, P. 1978. Macroeconomics. Homewood: Richard D. Irwin.

Woodford, M. 2002. Interest and Prices. Unpublished manuscript, chapter 2.

Young, W. 1987. Interpreting Mr Keynes - The IS-LM Enigma. Cambridge: Polity Press. 
